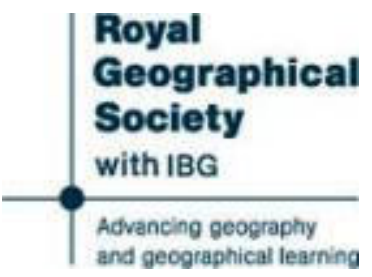

Russian Navigators in the Arctic Ocean in 1895-96

Author(s): J. Shokalsky

Source: The Geographical Journal, Vol. 12, No. 2 (Aug., 1898), pp. 172-176

Published by: The Royal Geographical Society (with the Institute of British Geographers)

Stable URL: http://www.jstor.org/stable/1774465

Accessed: 22-03-2015 11:43 UTC

Your use of the JSTOR archive indicates your acceptance of the Terms \& Conditions of Use, available at http://www.jstor.org/page/info/about/policies/terms.jsp

JSTOR is a not-for-profit service that helps scholars, researchers, and students discover, use, and build upon a wide range of content in a trusted digital archive. We use information technology and tools to increase productivity and facilitate new forms of scholarship. For more information about JSTOR, please contact support@jstor.org.

The Royal Geographical Society (with the Institute of British Geographers) is collaborating with JSTOR to digitize, preserve and extend access to The Geographical Journal. 
the cause of changes of climate all over our globe, and one of the most vital geological questions is now to ascertain what was the real composition of the Tertiary flora, not only in the temperate zone, but especially in the arctic and antarctic regions. What was the extent of change in climate which we are bound to admit?

Let me also add that, since botanists have so well proved lately that the flora of each separate region of the globe is a direct descendant, and bears the stamp of the flora which clothed that same region in Tertiary times, the thorough and full knowledge of the Tertiary flora, in all the parts of the globe, becomes a matter of first importance for the evolutional botanist.

Taking everything into consideration, it is no exaggeration to say that, once there is a hope of discovering new beds of Tertiary plants in Sannikoff Land and Bennet islands, this hope alone, apart from all other geographical and oceanographical considerations so well indicated by Baron Toll, would be a sufficient reason for sending out an expedition for the exploration of these Tertiary deposits.

The same applies in full, and even much more, to the necessity of sending out an antarctic expedition to explore the Tertiary plants, the presence of which has been indicated by both Carlsen and Borchgrevinls.

\section{P. KropotKin.}

\section{RUSSIAN NAVIGATORS IN THE ARCTIC OCEAN IN 1895-96.*}

\section{Communicated by Colonel J. SHOKALSKY. $\dagger$}

The special expedition organized by the Ministry of Marine in 1894 to explore the estuaries of the Obi and Yenisei and part of the Kara sea, wintered at Yeniseisk, and on the approach of spring was engaged in repairing the vessels-the s.s. Lieut. Ovtsin and sailing barge Lieut. Skuratov, the former drawing $8 \frac{1}{2}$ feet of water.

In the previous year (1894) they had made a successful trial of the coal obtained from the Alexander Nevsky mine, near one of the right tributaries of the Yenisei-the Dudiuka, and, finding its quality to be not inferior to that of English coal, decided on making exclusive use of it for the future.

While these preparations were being made, the commander of the expedition, Lieut.-Colonel A. J. Vilkitsky, together with Lieut. K. V. Ivanov, determined by telegraph the difference in Jongitude between Yeniseisk and Krasnoyarsk, the former serving as the base for the astronomical work of the expedition. Vilkitsky also conducted, in 1894 and 1896, a series of observations with an apparatus of reversible pendulums by Repsold belonging to the Imperial Russian Geographical Society, by whose desire these observations were undertaken.

On June 15 the expedition left the town of Yeniseisk by the river, and on their way down fixed the position of the village of Gelahino, and observed the magnetic elements at this place and at Dudinsk, where they also took pendulum observations. On July 17 they reached the estuary of the river, and entered the sea to the west of Sibiriakov island. Finding, however, the Gulf of Yeniseisk still

* Map, p. 224.

+ Colonel Shokalsky, who has obligingly forwarded this report containing data from unpublished sources, and three charts of this northern navigation, corrected according to recent observations, besides the sketch-map alluded to hereafter, is the Secretary of the Physical Section of the Imperial Russian Geographical Society. He was one of the Russian delegates and a Vice-President at the International Geographical Congress held in London in 1895, at which he communicated a paper on the "Maritime Route to Siberia " (see 'Report of the Sixth International Geographical Congress,' p. 239). 
obstructed by ice, they turned back, and spent a week in surveying the Korsakov group of islands and the south coast of the gulf. They also succeeded in fixing a position on the south coast of Sibiriakov island, and carried out magnetic observations there. On the conclusion of this work, they made a second attempt to enter the open sea near Mateh Saleh, but were once more obliged to retire southwards on account of the ice. They accordingly went to an anchorage at Zverevo, near the entrance to the Gulf of Yeniseisk, situated on the west coast. Here they experienced a storm of three days' duration, and then again put to sea, but were caught in a second storm off Sibiriakov island, which caused them no further damage than the loss of an anchor, though they were in some peril of being wrecked on the sandbanks off this island. On August 9 they resumed their voyage, meeting with two floes of rotten ice drifting northward from Lake bay. Forcing their way through these, they stood towards that part of the peninsula of Mateh Saleh visited the previous year by the Lieut. Ovtsin. Finding a depth of only 15 feet near the cape, they went north and then east to get more sea-room. Here they met with a large sandy island, which they rounded by keeping to the 5 -fathom limit, having the ice-belt in sight to the northward the whole way. They coasted along this island for 30 miles, fixed its position on the chart, and discovered that its southern extremity, ending in a steep cape, bore a complete resemblance to the land seen and described by Lieut. Schwede of the s.s. Lieut. Malygin in 1893.

They now set their course for Biely island, intending to fix its position, but thick weather and the arduous work they had befure them of surveying the almost unknown Gulf of Obi rendered further delay inexpedient; so, without waiting for fair weather, they turned southwards and entered the wide Gulf of Obi, stretching along the meridian for 400 miles. The navigation here was not difficult, the depth throughout being 10 to 12 fathoms, and no ice being met with. While at anchor off Cape Three Points, at the entrance of Tazov bay, they rode out a storm with the loss of only one cable.

Astronomical observations proved that the whole of the east coast of the gulf was incorrectly placed on the chart, and required shifting 40 miles to the westward, while the position of Cape Three Points was incorrect to the extent of 55 miles.

On reaching the southern part of the bay, they attempted to approach the mouth. of the river Nyda or Nadim, but found this impossible owing to shallows, the south wind which had blown persistently for three weeks having driven the water to the northward, and lowered the depth on the bar of the Obi. Four days were spent in discovering the channel, and it was August 24 before they entered the so-called Hamanelsky Obi, the northern channel of the delta, having previously fixed the position of Entrance island and Cape Hamanelsky. On August 30 they arrived at Obdorsk after a successful season's navigation in the Arctic ocean and Gulf of Obi.

The results obtained include accurate positions and definitions of the coasts of the Gulf of Yeniseisk, Sibiriakov island, and the east side of the Gulf of Obi; astronomical positions along the rivers Yenisei and $\mathrm{Obi}$; and a continuous series of magnetic observations from Yeniseisk to Port Dickson and along the Obi. It was found that both sides of the Gulf of Yeniseisk, east and west of Sibiriakov island, were equally deep and free from all hidden dangers. The west coast is more sheltered than the east, but not so accessible, except in clear weather, because Sibiriakov island, which has to be passed at a distance of 8 miles, lies low and cannot be sighted in hazy weather, and is, moreover, surrounded by shoals. By going east, navigators may run a straight course from Cape Mateh Saleh to the North-eastern islands, and from these may pass Sibiriakov island in any weather. The North-eastern islands, being about 200 feet above water and very steep, are 
easily approachable. The island discovered by the expedition to the north of Cape Mateh Saleh may be passed in clear weather at a distance of one or even half a mile; but in fog a more northerly course should be held, in soundings of not less than 7 to 8 fathoms.

Neither is the navigation of the Gulf of Obi dangerous. Keeping the east coast in sight from Cape Droviany, they had even soundings gradually diminishing as they went south, and it is only on the west coast off the Hamanelsky Obi, opposite the Yada, that shoals are frequent. The navigation of this gulf is, moreover, facilitated by the fact of the bottom being soft mud, and only sand on the banks. These too begin gradually, so that when the soil brought up by the lead is gritty, precautionary measures have to be taken. There are no rocks either in the gulf or the river Obi.

The navigation of the Yenisei as far as the town of Yeniseisk showed a depth throughout of 4 fathoms. The channel discovered in 1894 off Cape Gostinny was definitively surveyed in 1895, and found to have a depth of not less than 4 fathoms near Cape Doroféyev. Henoe it is superior in every way to the older channel, which has only 15 feet of water, and the Lukovaia arm forms a natural harbour accessible to ocean steamers.

Meteorological and hydrographical observations of tides and currents were systematically undertaken, and a variety of notes and collections relating to natural history, anthropology, etc., were made by Midshipman Botkin, M.D. The length of the seconds pendulum was observed in four places, the northernmost of these being on the North-eastern islands in lat. $73 \frac{1}{2}^{\circ}$ (Port Dickson).

In 1896 the expedition left the city of Tobolsk on June 4, and entered the Gult of Obi on the 24th of this month. By August 11 they had completed their survey of the southern part of this gulf and proceeded northwards; on August 22 they entered Yugor strait, and on September 16 arrived at Archangel.

Descending the Obi, they fixed the positions of the village of Elizarovo, the town of Beriosovsk, and the village of Obdorsk, filled in soundings on existing charts, and corrected shore-lines, changes having taken place at the river-bends owing to spring floods. The lesser Obi was navigated from Beriosovsk, the maps of the greater Obi having been corrected the previous year.

The river entrances were carefully examined, but none were found deeper than 9 feet towards the left coast. Crossing to the right, they ran a line of soundings along the bar, and found a depth of 12 feet under the right coast, all other parts averaging 9 to 10 feet. This proves that vessels drawing 12 feet and upwards cannot enter the Obi. Hence it became necessary to discover a sheltered bay where large steamers might safely discharge their cargoes, and thus secure the importance to commerce of the mighty Obi system. Such a harbour was discovered about 20 miles north of Cape Yam Saleh, with 17 feet of water, only exposed to light, rollers with a wind from the opposite right shore. This bay, named "Nahodka" (Discovery) bay, has been surveyed in 1897 by an officer of the hydrographical service specially sent for the purpose.

Having completed their survey of the bar, they sketched in the left coast of the gulf and the southern part of the right coast. Numerous sandbanks were found along the furmer, but none near the latter. Neither were there serious inaccuracies in former charts to correct, as was the case in the previous year's survey of the east coast. Only here and there was it found necessary to shift the coast-line a little to the west. This result might have been anticipated, owing to the circumstance of the survey of the west coast having been corrected in the second decade of the present century, while that of the right or east coast refers back to the Great North Russia expedition about the year 1730 . 
In rounding Biely island fog interrupted the survey, and no good positions could be fixed, but the soundings led to the belief that existing charts of this part are fairly accurate.

There is now nothing to hinder this northern navigation, and no systematic survey will have to be undertaken in the future; occasional corrections may be made as the opportunity occurs, and next summer it would be advisable to send an officer overland to examine in detail the bay near the bar of the Obi river.

Four astronomical positions were fixed on the coast of the gulf, besides numerous observations from the deck of the vessel; the position of the church in Yugor strait was also fixed, and the magnetic elements ascertained in seven places. In Tobolsk itself, as well as in Beriozovsk, Obdorsk, and Yugor strait, observations with the pendulum were also made. Meteorological and hydrographical observations were continued every four hours. The weather was altogether unfavourable, and on entering the Kara sea the two vessels, the s.s. Lieut. Ovtsin and the barge in tow, were for four days exposed to a violent storm from the north, south-west, south, and north-west, accompanied by fog and rain. The steamer ran short of coal, and had it not been for their adopting the novel expedient of coaling by slinging the sacks on the tow-rope and hauling them by means of a block and pulley from the barge to the steamer, it might have fared badly with them. By dint of incessant exertion on the part of officers and men the furnaces were kept supplied, and the little steamer with her charge weathered the storm.

The incidents of this storm are told by Colonel Shokalsky, but we are obliged, for want of space, to curtail his narrative.

When the weather at last moderated, and they were so fortunate as to enter Yugor shar or strait, one of the steamer's screws was disabled, the stock of coal was reduced to one sack and a half, and the officers and crews of both vessels were in a state of exhaustion. In Yugor strait they met with two English steamers at anchor, waiting the arrival of Captain Wiggins. At the request of the Englisb, they were supplied with the Russian maps, and it was probably due to these (though we are not told so) that these English vessels accomplished their voyage to the Yenisei so satisfactorily-one proceeded up the river, the other discharged cargo and returned safely to Norway. Acts of courtesy such as these deserve to be recorded, because they may help to allay that feeling of irritation which characterizes the relations of their respective governments in other parts of the world.

The sketch-map accompanying this paper is compiled from charts kindly supplied by Colonel Shokalsky.

Besides the above surveys, the Jigit cruiser, sent to the Glacial ocean in 1895 to protect the Russian fisheries in those seas, took out officers of the Hydrographical Department-Denisobransky and Jdanko-by whom the following surveys were made :-

1. A sketch-map of-

(a) The southern part of Pechenga bay (Varanger fiord).

(b) Cape Sétinsky and Volokov bay at the entrance to Kola bay.

(c) The southern part of the Kola bay.

(d) The straits of Kildyn.

(e) Major station and Voroniye Ludki.

$(f)$ The southern part of Catherine harbour.

2. Boat soundings of-

(a) Pechenga bay (Varanger fiord).

(b) Waida bay.

(c) Kola bay.

(d) Teribersky bay.

(e) Part of the roadstead beyond the Yokan islands. 
3. One hundred and seventy-one marine soundings.

4. Two hundred and seventy observations on the temperature and density of the surface water, and twenty-one series at different depths.

5. The entrances to Kola bay and Yokanka were buoyed.

6. Magnetic observations of all three elements at Kolguev island, Matochkin shar, Lesser Karmakul, Mushroom bay, and Catherine harbour.

7. Triangulation of church and station of Karmaku].

8. Astronomical positions of Mushroom bay in Novaya Zemlia and Kolguev island.

This last piece of work gave a particularly interesting result. The observations were made near the mouth of the Goose river on the north-west coast of the island. Its position on Russian charts was lat. $69^{\circ} 27^{\prime} 30^{\prime \prime}$, long. $48^{\circ} 32^{\prime} 0^{\prime \prime}$; on English charts (Imray) the position given is lat. $69^{\circ} 27^{\prime} 30^{\prime \prime}$, long. $48^{\circ} 43^{\prime} 0^{\prime \prime}$, or $11^{\prime}$ east of the position assigned on Russian charts. According to Jdanko, it should be lat. $69^{\circ} 28^{\prime} 56^{\prime \prime}$, long. $48^{\circ} 51^{\prime} 9^{\prime \prime}$, i.e. nearly $19^{\prime}$ of arc to the east of the Russian position, and $7^{\prime}$ east of the English.

A third expedition for hydrographic work has now been sent to the Kara sea by the Russian Admiralty, also under the command of Colonel Vilkitsky, on a new steamer, the Pakhtusoff, constructed at Middleborough, England.

\section{UNITED STATES DAILY ATMOSPHERIC SURVEY.*}

\section{By WILLIS L. MOORE.}

The United States Weather Service has been in existence twenty-seven years. During the past twenty-five years the daily synoptic charts of the service have shown the most comprehensive atmospheric survey ever presented to the forecaster, or to the broad investigator of the fundamental principles of storms. The vast region now brought under the dominion of twice-daily synchronous observations embraces an area extending 2000 miles north and south, 3000 miles east and west, and so fortunately located in the interest of the meteorologist as to cut an important arc from the circum-polar thoroughfare of storms of the northern hemisphere. The extreme points of observation are Edmonton, in the Canadian province of Alberta, on the north-west; St. John's, Newfoundland, on the north-east; Key West, on the south-east; and San Diego, on the south-west. And arrangements are now complete for a co-operation with Mexico similar to that in operation with Canada, and which will in a few months extend the area of observation southward over Mexico and Yucatan.

A wonderful panoramic picture of atmospheric conditions is, by the aid of simultaneous measurements and the electro-magnetic telegraph joining the places of observation by a magic touch, thus presented to the trained eye of the forecaster. Each twelve hours the kaleidoscope changes, and a new graphic picture of actual conditions is shown. Where else can the meteorologist find such opportunity to study storms and atmospheric changes?

In the middle of the eighteenth century Franklin detected the rotary and progressive motions of storms; early in the nineteenth century Redfield and Espy contended over rival theories as to the mechanical principle involied in the rotation of storms; and a little later Maury studied the winds of the Atlantic ocean; still

* Paper read in Section E (Geography) at the Toronto Meeting of the British Association, August, 1897. 


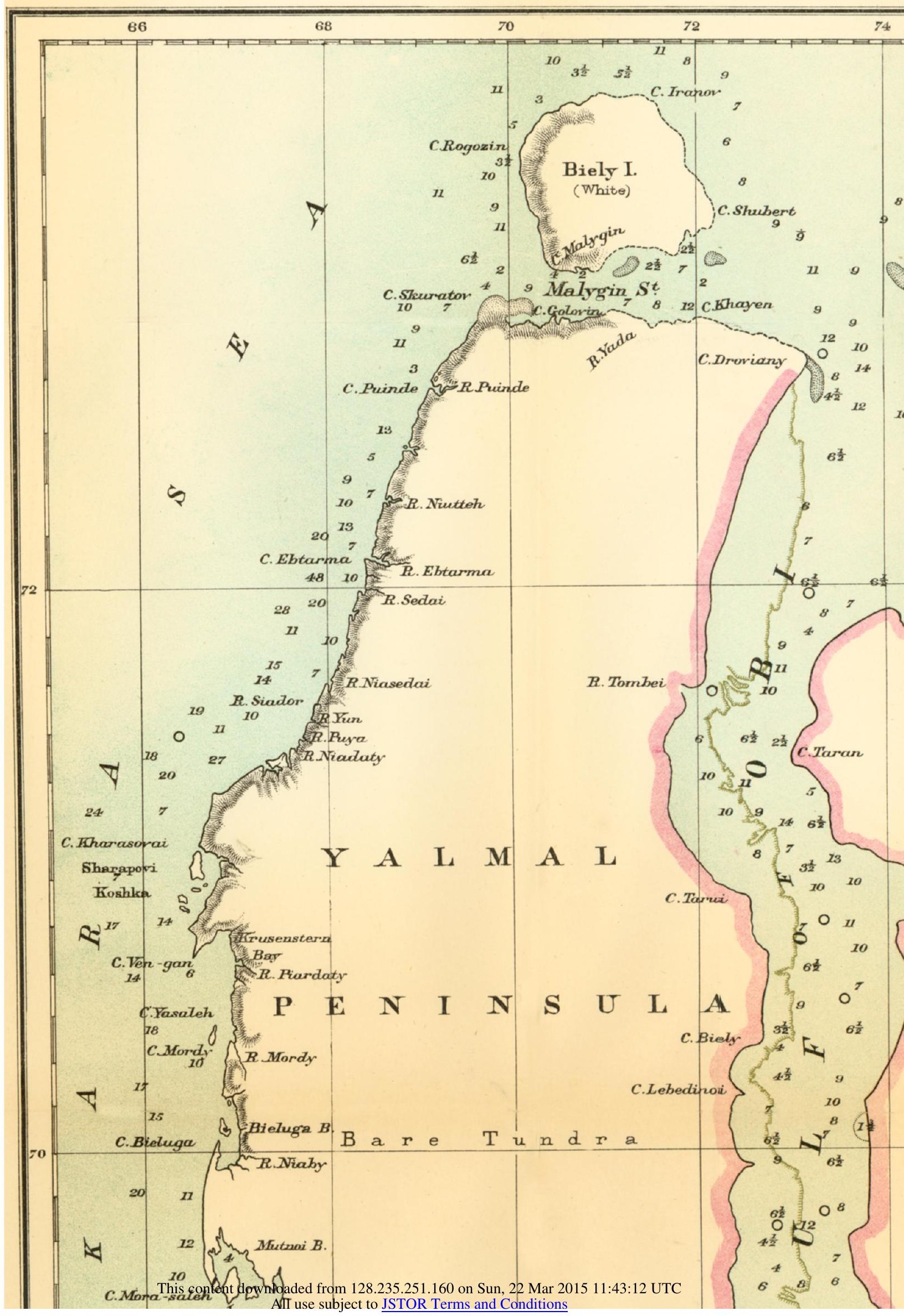




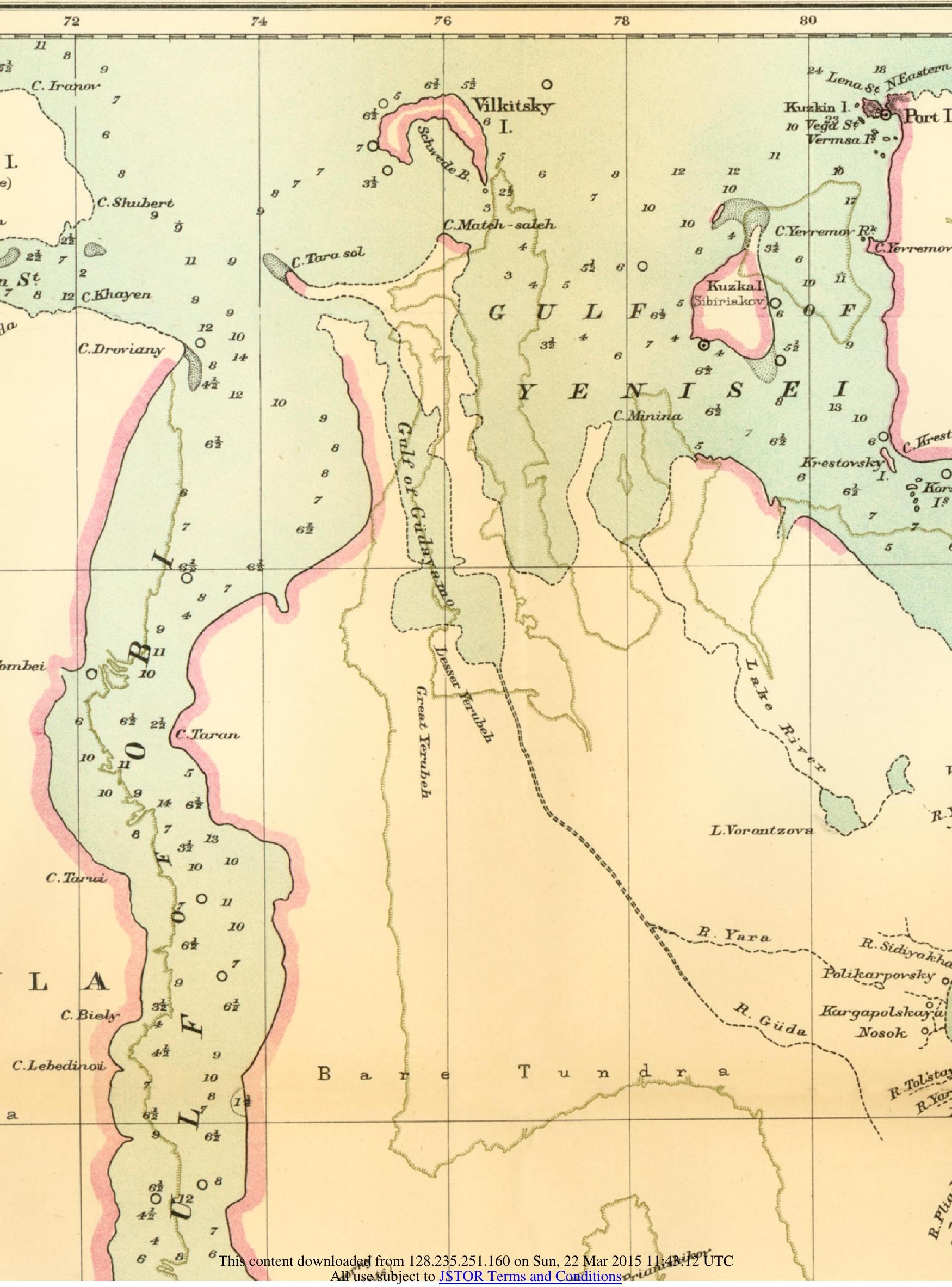




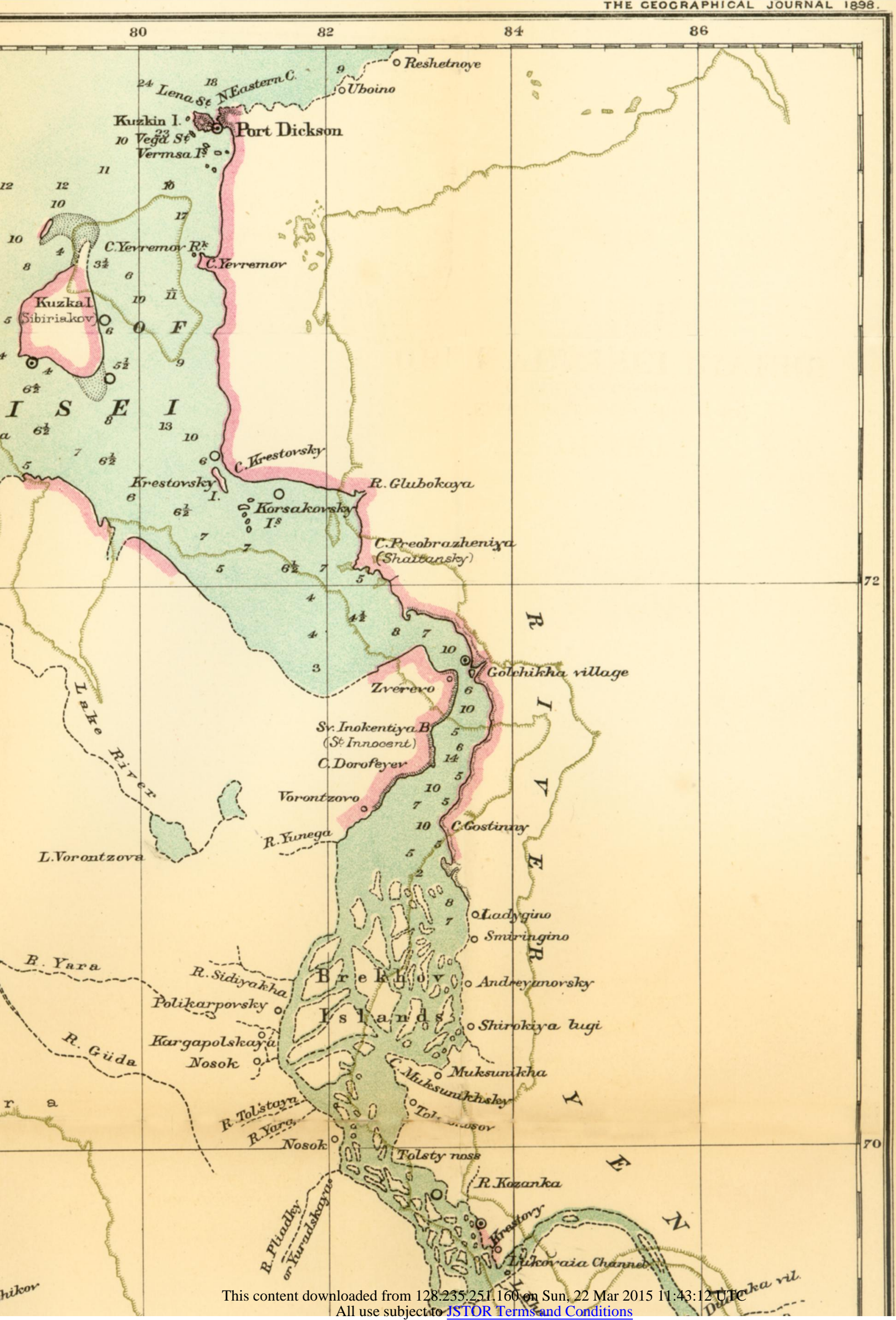




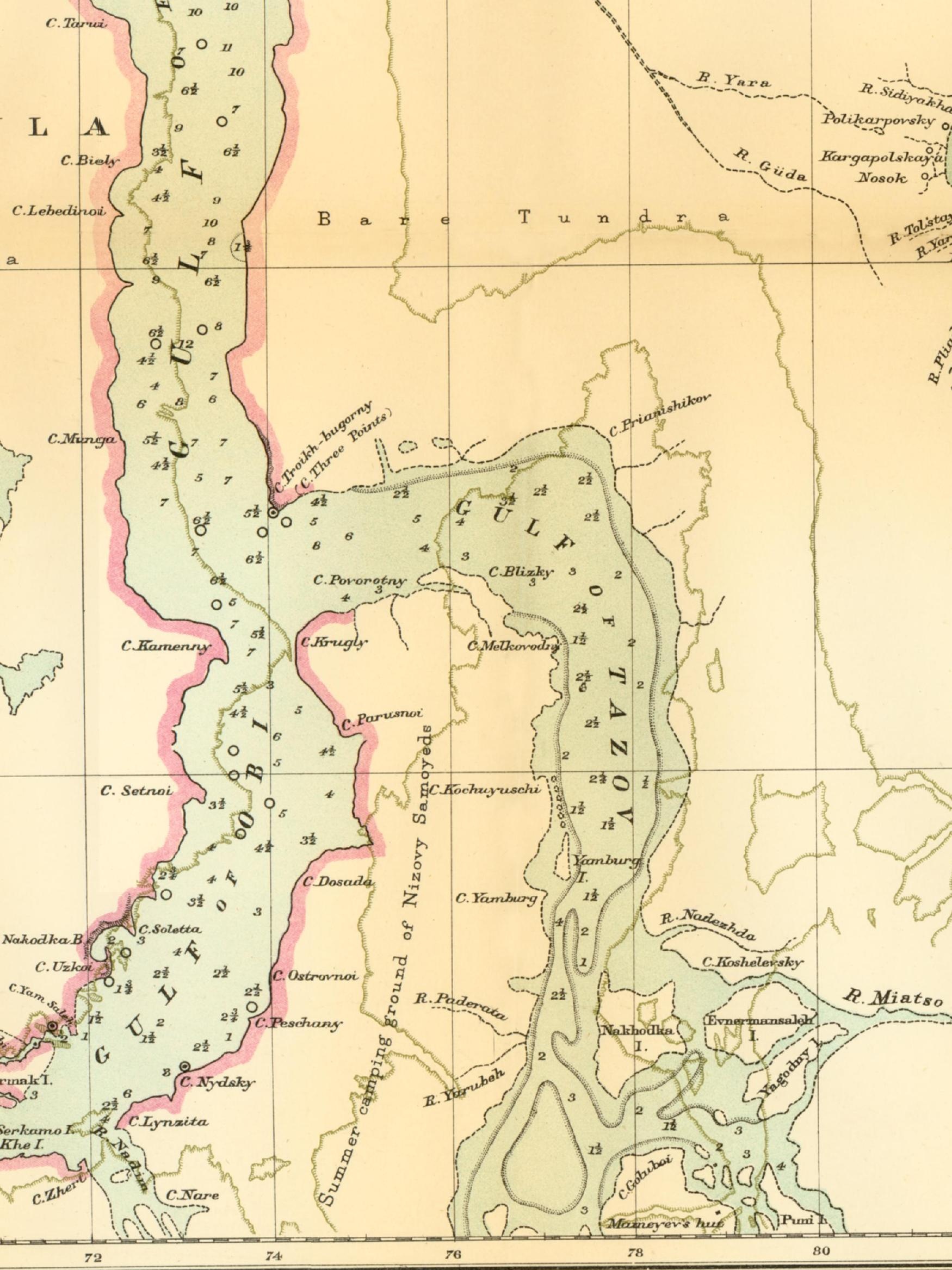

Published by the Royal Geographical Society. 
